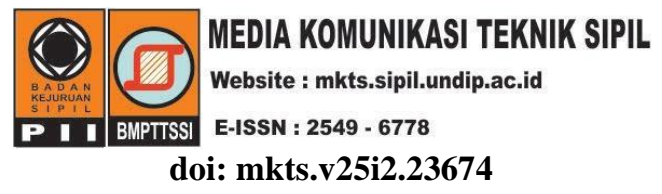

\title{
Analisis Nonlinier Tekuk Torsi Lateral pada Balok Baja Cellular
}

\author{
"Benny Gunawan Hung, Bambang Suryoatmono \\ Jurusan Teknik Sipil, Universitas Katolik Parahyangan, Bandung \\ *bennygunawanhung@gmail.com
}

Received: 16 Juni 2019 Revised: 2 September 2019 Accepted: 3 September 2019

\begin{abstract}
One of many buckling modes that could occur on the beam is lateral-torsional buckling. Lateral torsional buckling could result in lateral deformation and torsion of section. In the AISC 360-16 Spesification, an equation is provided to calculate lateral-torsional buckling critical moment of prismatic I section beam. For cellular beams (I section beam with circular openings), AISC Design Guide 31 states that the lateraltorsional buckling critical moment should be checked in accordance with AISC Specification using gross section properties. With this assumption, thus, the design guide ignores the existence of circular opening on the web, which can cause a reduction of lateral-torsional buckling critical moment. In this study, lateraltorsional buckling analysis on cellular beam with simple support loaded by distributed transversal load has been done - the analysis utilized finite element based software. From the analysis, the critical moment is lower than AISC 360-16 critical moment with the assumption of prismatic I section beam, with the maximum difference percentage of $43,58 \%$. Based on this study, a correction factor has been obtained to estimate the critical moment of cellular beams by using equation on AISC 360-16.
\end{abstract}

Keywords: Buckling analysis, cellular beam, critical moment, lateral torsional buckling

\begin{abstract}
Abstrak
Salah satu ragam tekuk yang terjadi pada balok adalah tekuk torsi lateral. Tekuk torsi lateral pada balok mengakibatkan terjadinya peralihan penampang secara lateral disertai torsi pada penampang. Pada spesifikasi desain AISC 360-16, disediakan persamaan untuk menghitung momen kritis tekuk torsi lateral pada balok berpenampang I prismatis. Untuk balok cellular (balok berpenampang I dengan bukaan berbentuk lingkaran), AISC Design Guide 31 menyatakan bahwa momen kritis tekuk torsi lateral harus dihitung sesuai dengan persamaan spesifikasi desain AISC 360-16, yaitu dengan asumsi data penampang I prismatis. Dengan asumsi demikian, berarti AISC Design Guide 31 mengabaikan adanya bukaan pada bagian web yang dapat menyebabkan berkurangnya momen kritis tekuk torsi lateral. Pada studi ini, dilakukan analisis tekuk torsi lateral balok cellular di atas tumpuan sederhana yang mengalami beban terbagi rata dengan berbagai panjang bentang dan ukuran penampang. Analisis dilakukan dengan bantuan perangkat lunak berbasis elemen hingga. Dari analisis tersebut, diperoleh momen kritis yang lebih rendah dibandingkan dengan momen kritis yang dihitung dengan AISC 360-16 dengan asumsi balok berpenampang I prismatis, dengan persentase perbedaan maksimum 43,58\%. Berdasarkan studi ini, diperoleh faktor koreksi yang dapat digunakan untuk mengestimasi momen kritis balok cellular menggunakan persamaan yang terdapat pada spesifikasi desain AISC 360-16.
\end{abstract}

Kata kunci: Analisis tekuk, balok celullar, momen kritis, tekuk torsi lateral

\section{Pendahuluan}

Stabilitas struktur menjadi suatu komponen yang penting dalam menentukan kemampuan struktur menerima beban. Struktur elastis yang stabil akan mengalami peralihan yang proposional terhadap beban yang terjadi. Pada struktur yang tidak stabil, perubahan kecil pada gaya akan menyebabkan perubahan yang signifikan pada peralihan. Jika perubahan ini cukup besar, atau pada bagian kritis 
sebuah struktur, ketidakstabilan lokal maupun elemen akan menyebabkan keruntuhan seluruh struktur (Galambos \& Surovek, 2008). Salah satu ketidakstabilan yang dapat terjadi pada komponen struktur balok adalah fenomena tekuk. Fenomena tekuk mengakibatkan struktur dapat runtuh sebelum mencapai leleh. Tekuk pada komponen struktur dapat dibagi menjadi tekuk lokal dan tekuk global. Salah satu jenis tekuk global yang dapat terjadi pada balok penampang I adalah tekuk torsi lateral. Tekuk torsi lateral adalah peralihan penampang secara lateral disertai dengan torsi penampang yang diakibatkan oleh momen lentur.

Balok ideal tidak akan berdeformasi secara lateral hingga beban yang bekerja menyebabkan momen kritis elastis. Pada keadaan ini, ketidakstabilan tercapai dan deformasi yang besar terjadi secara lateral secara tiba-tiba. Karena material pada balok ini elastis, maka deformasi besar dapat terjadi dan keadaan seimbang baru dapat terjadi ketika struktur mengalami deformasi. Setiap peningkatan kecil beban, akan menghasilkan deformasi tambahan yang besar (Höglund, 2006).

Balok pada kondisi nyata memilliki kapasitas yang tereduksi dibandingkan dengan balok ideal yang diakibatkan oleh ketidaksempurnaan, tegangan sisa dan lain-lain. Pada balok nyata, ketidaksempurnaan sudah terjadi saat beban mulai bekerja. Deformasi awal ini meningkat ketika beban ditingkatkan. Ketika beban semakin mendekati beban kritis, peralihan mulai meningkat secara signifikan akan tetapi tidak akan mencapai momen kritis elastis. Kegagalan ini disebabkan oleh respon material plastis, ketidaklinieran geometri dan kemungkinan tekuk lokal (ibid.).

Pada spesifikasi desain AISC 360-16 telah disediakan persamaan untuk menghitung momen kritis tekuk torsi lateral elastis dan inelastis untuk balok penampang I yang prismatis. Tekuk torsi lateral elastis terjadi saat momen kritis tercapai sebelum tegangan pada balok mencapai tegangan leleh. Sedangkan tekuk torsi inelastis terjadi saat momen kritis tercapai setelah tegangan pada sebagian balok mencapai tegangan leleh. Momen kritis tekuk torsi elastis $\left(\mathbf{M}_{\text {cre }}\right)$ dapat dilihat pada Persamaan 1, dan momen kritis tekuk torsi inelastis $\left(\mathrm{M}_{\mathrm{cri}}\right)$ dapat dilihat pada Persamaan 2.

$M_{\text {cre }}=F_{c r} S_{x}$

$M_{\text {cri }}=C_{b}\left[M_{p}-\left(M_{p}-0,7 F_{y} S_{x}\right)\left(\frac{L_{b}-L_{p}}{L_{r}-L_{p}}\right)\right]$

Besaran $S_{x}$ adalah statis momen terhadap sumbu kuat penampang, $C_{b}$ adalah faktor modifikasi momen tak seragam, $E$ adalah modulus elastisitas material, $L_{b}$ adalah panjang bentang balok tak tertumpu lateral, $J$ adalah konstanta torsi, $h_{o}$ adalah jarak antara pusat elemen flens atas dan flens bawah penampang, $F_{y}$ adalah tegangan leleh baja, $F_{c r}$ adalah tegangan kritis tekuk torsi lateral yang dirumuskan pada persamaan 3, dan $r_{t s}$ adalah radius girasi efektif tekuk torsi lateral yang dapat dihitung dengan Persamaan 4.

$$
\begin{aligned}
& F_{c r}=\frac{C_{b} \pi^{2} E}{\left(\frac{L_{b}}{r_{t s}}\right)^{2}} \sqrt{1+0,078 \frac{J c}{S_{x} h_{o}}\left(\frac{L_{b}}{r_{t s}}\right)^{2}} \\
& r_{t s}=\frac{\sqrt{I_{y} C_{w}}}{S_{x}}
\end{aligned}
$$

Spesifikasi AISC 360-16 (2016), memberi klasifikasi kedua jenis tekuk torsi lateral berdasarkan panjang balok yang tak tertumpu lateral. Apabila $L_{b}$ lebih besar dari $L_{r}$, maka balok akan mengalami tekuk torsi lateral elastis. Balok akan mengalami tekuk torsi lateral inelastis apabila $L_{p}<L_{b}<L_{r}$. Apabila $L_{b}<L_{p}$, balok tidak akan mengalami tekuk torsi lateral dan momen kritis adalah sama dengan momen plastis. Besaran $\mathrm{L}_{\mathrm{p}}$ dan $\mathrm{L}_{\mathrm{r}}$ dapat dihitung menggunakan persamaan 5 dan 6 yang disediakan spesifikasi desain AISC.

$$
\begin{aligned}
& L_{p}=1,76 r_{y} \sqrt{\frac{E}{F_{y}}} \\
& L_{r}=1,95 r_{t s} \frac{E}{0,7 F_{y}}
\end{aligned}
$$

$$
\sqrt{\frac{J c}{s_{x} h_{o}} \sqrt{\left(\frac{J c}{s_{x} h_{o}}\right)^{2}+6,76\left(\frac{0.7 F_{y}}{E}\right)^{2}}}
$$

Pada balok penampang I prismatis, modifikasi geometri sering dilakukan untuk memenuhi kebutuhan desain. Salah satu modifikasi geometri balok baja penampang I adalah balok baja kastela. Modifikasi tersebut menghasilkan balok berpenampang I yang memiliki lubang pada bagian web. Balok cellular merupakan salah satu jenis balok baja kastela dengan jenis bukaan lingkaran pada web balok. Pabrikasi balok cellular dilakukan dengan memotong balok berpenampang I prismatis pada bagian web dengan membuat potongan horizontal dan setengah lingkaran menjadi dua bagian, kemudian kedua bagian tersebut disambungkan kembali dengan cara pengelasan pada bagian potongan horizontal. Ilustrasi proses pabrikasi balok cellular ditampilkan pada Gambar 1 .

Kekuatan balok berpenampang I prismatis terhadap tekuk torsi lateral sangat dipengaruhi oleh kekakuan lentur, kekakuan torsi St. Venant dan kekakuan torsi pilin penampang. Pada balok cellular, ketiga komponen kekakuan tersebut lebih kecil dibandingkan dengan balok penampang I prismatis dengan ukuran yang sama. Dengan demikian, momen kritis tekuk torsi lateral balok 
celullar lebih kecil dari pada balok prismatis dengan ukuran yang sama.

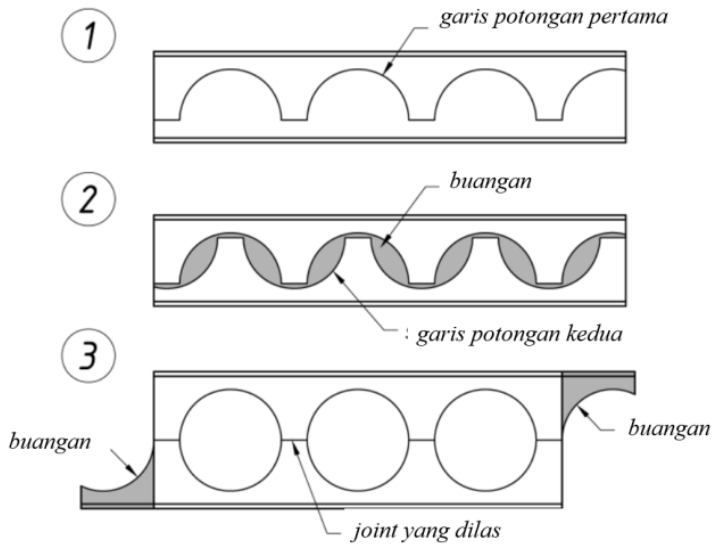

Gambar 1. Proses pabrikasi balok cellular (Krzysztof, 2016)

Berdasarkan AISC Design Guide 31 (2016), perhitungan momen kritis tekuk torsi lateral balok cellular diperbolehkan menggunakan persamaan yang sama pada spesifikasi AISC 360-16 Bab F, yaitu Persamaan 1 dengan mengganggap properti penampang balok cellular sama dengan penampang balok prismatis. Dengan adanya anggapan tersebut, berarti AISC Design Guide 31 mengabaikan adanya lubang lingkaran pada bagian web yang sebenarnya mengurangi momen kritis tekuk torsi lateral.

Beberapa penelitian telah dilakukan mengenai tekuk torsi lateral pada balok kastela dengan bukaan berbentuk heksagon. Pada studi yang telah dilakukan oleh Wakchaure dan Sagade (2012), dilakukan pemodelan menggunakan metode elemen hingga terhadap balok kastela dengan bukaan berbentuk heksagon yang bervariasi terhadap tinggi total penampang. Pada studi tersebut, kekakuan lentur balok kastela menurun seiring dengan meningkatnya tinggi bukaan dan disimpulkan balok kastela dengan bukaan heksagon memiliki kemampuan layan yang optimum dengan tinggi bukaan 06 kali tinggi total balok.

Studi lainnya dilakukan oleh Jamadar A. M dan Kumbhar P. D. (2015) untuk memperoleh ukuran bukaan balok kastela yang optimal terhadap kegagalan kriteria Von-Mises. Bentuk bukaan yang dianalisis adalah lingkaran dan wajik. Analisis dilakukan dengan menggunakan metode elemen hingga dengan bantuan perangkat lunak ABAQUS. Struktur balok kastela dengan perletakan sederhana dibebani beban terpusat pada sepertiga bentang. Diperoleh kesimpulan bahwa perbandingan tinggi bukaan dengan tinggi total penampang yang menghasilkan struktur balok kastela yang optimum adalah 0,7 untuk bukaan bentuk lingkaran dan 0,67 untuk bukaan bentuk wajik.

Showkati (2008) pada studinya telah mengusulkan beberapa persamaan empiris untuk memprediksi koefisien lentur $C_{b}$ untuk balok kastela. Hasil analisis yang diperoleh juga dibandingkan terhadap data dan studi-studi sebelumnya. Berdasarkan studi ini, diperoleh bahwa kapasitas lentur-elastis balok kastela dan balok berpenampang I yang prismatis memiliki persentase perbedaan pada rentang $4,9 \%$ hingga $8,6 \%$.

Pada studi oleh Tudjono, et al. (2017), dilakukan analisis numerik dan uji eksperimental terhadap tiga spesimen balok kastela dengan bukaan berbentuk oval, yaitu CB1, CB2 dan CB3. Balok CB1 dan CB2 adalah balok kastela dengan bukaan oval horizontal yang memiliki konfigurasi yang sama tetapi dengan lokasi pembebanan yang berbeda. Sedangkan, bukaan pada CB3 adalah oval vertikal. Balok kastela yang digunakan merupakan modifikasi dari balok asli prismatis berpenampang IWF $150 \times 75 \times 5 \times 7$.

Balok tersebut tertumpu sederhana dengan pembebanan dua titik pada bagian lapangan balok. Pada kedua tumpuan, diberikan tumpuan rol sehingga penampang tidak dapat mengalami torsi tetapi masih dapat mengalami pilin. Ilustrasi tumpuan dan pembebanan balok ini ditampilkan pada Gambar 2. Melalui analisis metode elemen hingga, diperoleh hasil untuk CB1 dengan beban maksimum 169,17 kN dan peralihan vertical 12,32 mm, untuk CB2 dengan beban maksimum 163,34 dan peralihan vertikal $8,29 \mathrm{~mm}$ dan untuk CB3 dengan beban maksimum $128,75 \mathrm{kN}$ dan peralihan vertikal $13,03 \mathrm{~mm}$. Hasil ini sudah tervalidasi dengan hasil uji eksperimental yang menghasilkan rasio beban maksimum antara kedua uji sebesar 0,98 hingga 1,01 .

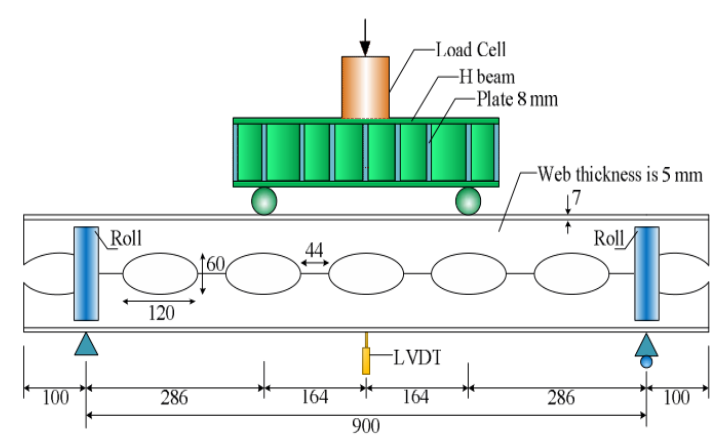

Gambar 2. Tumpuan dan pembebanan balok kastela bukaan oval (Tudjono et al. 2017)

Diperoleh kesimpulan bahwa pada balok kastela dengan bukaan oval horizontal menghasilkan balok yang lebih kuat dengan rasio beban sebesar 1,02 
kali lebih besar daripada balok yang asli. Sedangkan, balok kastela dengan bukaan oval vertikal menghasilkan rasio beban sebesar 0,78 daripada balok yang asli sehingga spesimen balok ini menghasilkan balok yang lebih lemah dibandingkan dengan balok yang asli.

Kwani dan Wijaya (2017) melakukan analisis keruntuhan pada balok kastela dengan bukaan berbentuk heksagon (tipe honeycomb) yang mengalami tekuk torsi lateral. Analisis keruntuhan dilakukan secara numerik menggunakan perangkat lunak yang memanfaatkan metode elemen hingga. Balok kastela dimodelkan dengan tumpuan sederhana dan dilakukan beberapa variasi panjang bentang dan ukuran penampang. Pembebanan yang dikerjakan pada balok berupa momen ujung dengan kondisi kelengkungan tunggal (single curvature) untuk berbagai rasio antara momen di kedua ujung. Berdasarkan hasil analisis, momen kritis balok kastela yang diperoleh dari metode elemen hingga tereduksi maksimum $42,31 \%$ dibandingkan dengan momen kritis penampang I tanpa bukaan dengan dimensi yang sama yang dihitung dengan menggunakan persamaan AISC 360-2010. Selain itu, dirumuskan sebuah persamaan untuk menghitung momen kritis tekuk torsi lateral balok kastela tipe honeycomb.

Pada studi yang dilakukan oleh Gunawan dan Suryoatmono (2017), dilakukan analisis riwayat waktu nonlinier untuk mensimulasikan perilaku balok yang dibebani beban tegak lurus pada sumbu utama penampang secara bertahap dari awal hingga tekuk torsi lateral terjadi. Dilakukan variasi pembebanan berupa beban terpusat dan beban terbagi rata pada balok yang tertumpu sederhana. Material yang digunakan bersifat nonlinier dan memiliki tegangan sisa. Berdasarkan studi ini, dirumuskan persamaan yang menggunakan faktor reduksi untuk mengestimasi momen tekuk torsi lateral pada balok honeycomb yang mengalami lentur pada arah sumbu kuat berdasarkan persamaan momen kritis spesifikasi desain AISC 360-10. Ketika panjang bentang tak tertumpu lateral $\left(L_{b}\right)$ balok honeycomb adalah enam kali atau lebih besar daripada $L_{p}$, maka faktor reduksi mendekati 1,0. Disimpulkan juga bahwa reduksi kekuatan tekuk torsi lateral balok bisa serendah 0,1 untuk balok dengan $L_{b}$ yang sangat pendek.

Penelitian mengenai tekuk torsi lateral pada balok cellular dilakukan oleh Nseir et al. (2012). Penelitian dilakukan secara numerik yang bertujuan untuk membandingkan momen tekuk torsi lateral elastis balok cellular dengan balok psimatis yang dihitung dengan menggunakan acuan desain Arcelor Mittal yang dinilai sangat konservatif. Adapun beberapa pertimbangan yang dapat menghasilkan kesimpulan bahwa acuan desain ini sangat konservatif, adalah: (1) efek stabilisasi pada flens yang mengalami tarik diabaikan, (2) kekakuan torsi seluruh struktur diabaikan, (3) Ttauan bahwa penampang $\mathrm{T}$ merupakan penampang terlemah mengabaikan adanya segmen web penuh yang berada di antara lubang.

Pada awal penelitian tersebut, dilakukan validasi untuk mengetahui tingkat akurasi analisis numerik terhadap hasil uji eksperimental. Dari analisis yang dilakukan, disimpulkan bahwa momen tekuk torsi lateral yang diperoleh dari analisis numerik menghasilkan momen kritis tekuk torsi lateral yang lebih kecil dibandingkan dengan hasil persamaan pada acuan desain Arcelor Mittal.

Pada studi ini, analisis dilakukan untuk mengetahui perilaku tekuk torsi lateral pada balok cellular secara numerik dengan metode elemen hingga (MEH). Tujuan dari analisis ini adalah memperoleh hubungan beban dan deformasi lateral, momen kritis dengan metode elemen hingga serta memperoleh faktor koreksi untuk menghitung momen kritis balok cellular terhadap tekuk torsi lateral spesifikasi AISC 360-16. Hasil dari analisis metode elemen hingga dibandingkan dengan perhitungan menggunakan persamaan momen kritis tekuk torsi lateral spesifikasi desain AISC 360-16 yang ditunjukkan dalam Persamaan 1 dan 2.

\section{Metode}

\section{Pemodelan struktur}

Pada studi ini, model yang dianalisis adalah balok cellular dengan tumpuan sederhana. Penampang di kedua ujung balok ditahan agar tidak dapat mengalami rotasi terhadap sumbu memanjang hanya dapat mengalami pilin. Pada pemodelannya, peralihan seluruh nodal penampang pada kedua ujung balok dalam arah lateral ditahan dan peralihan pusat penampang pada salah satu ujung balok ditahan dalam arah longitudinal balok. Beban terbagi rata dikerjakan pada seluruh permukaan bagian atas flens atas dan bagian bawah flens bawah. Hal ini dilakukan untuk mewakili beban yang bekerja pada pusat geser (shear center) penampang sehingga beban tidak menimbulkan efek destabilisasi terhadap torsi penampang.

Material balok yang digunakan adalah baja yang bersifat elastic perfecty plastic dengan $F_{y} 250 \mathrm{MPa}$ dan mengabaikan adanya tegangan sisa. Ukuran penampang yang digunakan adalah $\mathrm{CF}$ $225 \times 75 \times 5 \times 7$, CF $375 \times 125 \times 6 \times 9$, CF 525x175x7x11 dan CF 600x200x8x13. Variasi panjang bentang 
dilakukan untuk setiap profil. Variasi ukuran penampang dan panjang bentang ditampilkan pada Tabel 1.

Analisis dilakukan dengan menggunakan perangkat lunak ANSYS yang memanfaatkan metode elemen hingga. Metode elemen hingga adalah sebuah metode numerik untuk memperoleh solusi pendekatan terhadap berbagai bidang permasalahan.

Prinsip metode elemen hingga adalah menyelesaikan suatu permasalahan dengan membagi struktur menjadi elemen-elemen yang lebih kecil. Proses ini disebut dengan proses diskretisasi. Dengan menggunakan metode elemen hingga, solusi yang diperoleh adalah berupa solusi perkiraan. Ketelitian solusi ini dapat ditingkatkan dengan menggunakan jumlah elemen yang lebih banyak dan mengubah sifat elemen yang dapat mewakili struktur yang ditinjau (Cook, 2002).

Dengan metode elemen hingga, balok didiskretisasi sehingga terdiri atas elemen-elemen diskret yang saling terhubung. Pada studi ini, digunakan elemen diskret SHELL281 dengan ukuran maksimum $10 \mathrm{~mm}$. Elemen diskret SHELL281 memiliki 8 nodal pada satu elemen diskret dengan 6 derajat kebebasan untuk masingmasing nodal (Lee, 2014).

\section{Analisis tekuk}

Analisis tekuk dapat dibagi menjadi analisis tekuk linier dan tekuk nonlinier. Analisis tekuk linier (eigenvalue) memprediksi kekuatan teoritis tekuk struktur ideal elastis linier. Akan tetapi, adanya sifat ketidaksempurnaan dan ketidaklinieran pada struktur mengakibatkan kekuatan teoritis tekuk ini tidak tercapai. Pada analisis tekuk nonlinier, beban akan ditingkatkan secara perlahan untuk memperoleh tingkat beban yang menyebabkan sebuah struktur menjadi tidak stabil (Bak, 2014).

Dengan menggunakan perangkat lunak ANSYS, akan dilakukan analisis tekuk linier dan nonlinier pada balok cellular. Hasil analisis tekuk linier adalah ragam tekuk yang nantinya akan digunakan sebagai bentuk ketidaksempurnaan geometri pada analisis tekuk nonlinier.

Ketidaksempurnaan geometri yang digunakan pada analisis tekuk nonlinier adalah ragam tekuk torsi lateral yang terjadi pada ragam tekuk pertama pada analisis tekuk linier. Amplitudo dari bentuk ini diambil sebesar 1/1500 dari panjang bentang balok. Besaran ini diambil berdasarkan ketidaksempurnaan awal (initial out of straightness) izin yang memenuhi persamaan SSRC (Salmon, 2009). Pada analisis tekuk nonlinier, beban dikerjakan pada balok secara inkremental dengan metode kontrol beban (load control) sehingga balok yang telah diberi ketidaksempurnaan geometri akan runtuh ketika beban mencapai maksimum.

\section{Hasil dan Pembahasan}

\section{Verifikasi MEH terhadap AISC}

Untuk mengetahui tingkat akurasi analisis menggunakan metode elemen hingga, dilakukan perbandingan momen kritis antara analisis metode elemen hingga dengan momen kritis persamaan spesifikasi AISC 360-16. Struktur yang dianalisis adalah balok berpenampang I prismatis dengan ukuran $225 \times 75 \times 6.5 \times 9$ dengan variasi berbagai panjang bentang. Ragam tekuk torsi lateral yang terjadi ditampilkan pada Gambar 3.

Tabel 1. Variasi ukuran penampang dan panjang bentang

\begin{tabular}{cccccccc}
\hline Profil & $\begin{array}{c}\text { rts } \\
(\mathbf{m m})\end{array}$ & $\begin{array}{c}\text { Jumlah } \\
\text { bukaan }\end{array}$ & $\mathbf{L b}_{\mathbf{b}}(\mathbf{m m})$ & $\begin{array}{c}\text { Jumlah } \\
\text { bukaan }\end{array}$ & $\mathbf{L b}_{\mathbf{b}}(\mathbf{m m})$ & $\begin{array}{c}\text { Jumlah } \\
\text { bukaan }\end{array}$ & $\mathbf{L}_{\mathbf{b}}(\mathbf{m m})$ \\
\hline \multirow{3}{*}{ CF 225x75x5x7 } & & 11 & 2247,50 & 14 & 2828,75 & 17 & 3410,00 \\
& 19,23 & 12 & 2441,25 & 15 & 3022,50 & 18 & 3603,75 \\
& & 13 & 2635,00 & 16 & 3216,25 & - & - \\
\hline \multirow{2}{*}{ CF 325x125x6x9 } & \multirow{2}{*}{32,04} & 10 & 3418,50 & 13 & 4386,00 & 16 & 5353,50 \\
& & 11 & 3741,00 & 14 & 4708,50 & 17 & 5676,00 \\
& & 12 & 4063,50 & 15 & 5031,00 & 18 & 5998,50 \\
\hline
\end{tabular}



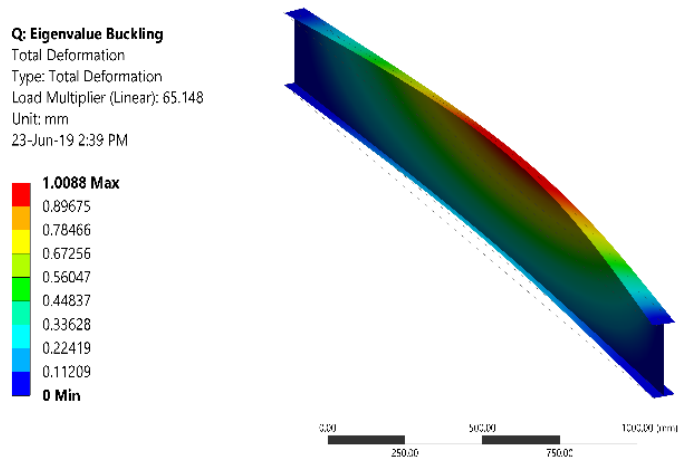

Gambar 3. Ragam tekuk torsi lateral balok WF $225 \times 75 \times 6,5 \times 9$

Berdasarkan hasil analisis tekuk torsi lateral, diperoleh perbandingan momen kritis analisis MEH $\left(M_{c r-M E H}\right)$ dengan momen kritis persamaan AISC $\left(M_{c r-A I S C}\right)$ yang ditabelkan pada Tabel 2. Berdasarkan Tabel 2, perbedaan $M_{c r-A I S C}$ dan $M_{c r-M E H}$ berkisar di antara 0,427 \% hingga 1,452\% sehingga dapat disimpulkan bahwa analisis tekuk nonlinier dengan metode elemen hingga memberikan hasil yang cukup akurat.

Tabel 2. Perbandingan momen kritis AISC dan metode elemen hingga

\begin{tabular}{cccc}
\hline $\begin{array}{c}\boldsymbol{L}_{\boldsymbol{b}} \\
(\mathbf{m m})\end{array}$ & $\begin{array}{c}\boldsymbol{M}_{\boldsymbol{c r} \text {-AISC }} \\
(\mathbf{k N m})\end{array}$ & $\begin{array}{c}\boldsymbol{M}_{\boldsymbol{c r} \text {-MEH }} \\
(\mathbf{k N m})\end{array}$ & $\begin{array}{c}\text { Perbedaan } \\
(\boldsymbol{\%})\end{array}$ \\
\hline 2247,50 & 31,216 & 30,763 & $-1,452$ \\
2828,75 & 23,372 & 23,231 & $-0,603$ \\
3410,00 & 18,081 & 18,158 & 0,427 \\
3991,25 & 14,742 & 14,818 & 0,512 \\
\hline
\end{tabular}

\section{Validasi MEH terhadap uji eksperimental}

Selain membandingkan momen kritis yang diperoleh dengan metode yang berbeda, diperlukan validasi analisis metode elemen hingga perangkat lunak ANSYS terhadap uji eksperimental. Uji validasi studi ini menggunakan data uji Nseir et al. (2012). Tesis magister yang ditulis oleh Sehwail (2013) melakukan analisis metode elemen hingga menggunakan perangkat lunak ABAQUS terhadap benda uji pada studi oleh Nseir et al. (2012).

Pada tesisnya, telah tersedia telah menyediakan data geometri balok cellular IPE 330 yang ditampilkan pada Gambar 4. Data penampang IPE 330 ditampilkan pada Tabel 3 dengan variabel D adalah diameter lubang dan variabel $\mathrm{S}$ adalah jarak pusat ke pusat antar lubang.

Balok dibebani dan ditumpu secara lateral pada titik yang berjarak $1945 \mathrm{~mm}$ dari kedua ujung balok sehingga panjang bentang tak tertumpu lateral $\left(\mathrm{L}_{\mathrm{b}}\right)$ adalah $7110 \mathrm{~mm}$. Pada kedua ujung balok digunakan tumpuan sederhana sehingga tidak dapat mengalami torsi penampang tetapi dapat mengalami pilin. Ilustrasi tumpuan dan pembebanan pada benda uji ditampilkan pada Gambar 5.

Tabel 3. Data penampang IPE 330

\begin{tabular}{|c|c|c|c|}
\hline & \multicolumn{2}{|c|}{$\begin{array}{c}\text { Dimensi penampang IPE } 330 \\
(\mathrm{~mm})\end{array}$} & \\
\hline & $\mathrm{H}$ & 446,2 & \\
\hline & B & 161,5 & \\
\hline & $t_{f}$ & 10,7 & \\
\hline & $t_{w}$ & 7,7 & \\
\hline & D & 345,0 & \\
\hline & $\mathrm{S}$ & 395,0 & \\
\hline & $0,5 P$ & & $0,5 \mathrm{P}$ \\
\hline 446.25 & 00 & 000 & \\
\hline
\end{tabular}

Gambar 4. Geometri balok cellular IPE 330

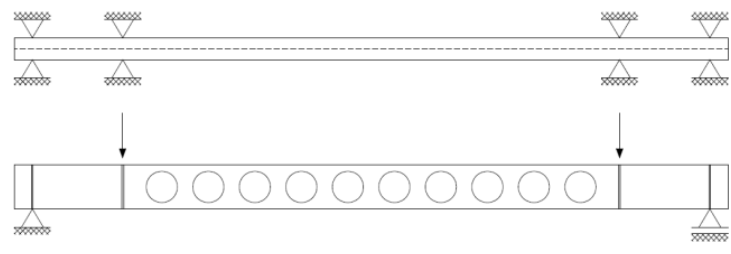

Gambar 5. Tumpuan dan letak beban benda uji IPE 330 (Nseir et. al., 2012)

Berdasarkan analisis metode elemen hingga pada balok cellular IPE 330 yang mengalami tekuk torsi lateral, diperoleh beban kritis $\left(\mathrm{P}_{\max }\right)$ sebesar $171,8 \mathrm{kN}$, peralihan vertikal maksimum $\left(\Delta_{\mathrm{V}}\right)$ sebesar 26,43 $\mathrm{mm}$ dan peralihan lateral maksimum $\left(\Delta_{\mathrm{H}}\right)$ sebesar 76,467 mm. Berdasarkan analisis ini, dibuat tabel perbandingan antara hasil uji eksperimental dan analisis numerik MEH yang ditampilkan pada Tabel 4. Berdasarkan Tabel 4 rasio antara hasil $\mathrm{MEH}$ terhadap uji eksperimental untuk $\mathrm{P}_{\max }, \Delta_{\mathrm{V}}$ dan $\Delta_{\mathrm{H}}$ secara berurutan adalah 1,027; 0,926 dan 0,814. Hubungan beban total dan peralihan vertikal benda uji IPE 330 untuk analisis MEH dengan perangkat lunak ANSYS (A), analisis MEH oleh Nseir et al. (2012) (B), uji eksperimental (C) dan studi ini ditampilkan pada Gambar 6.

Tabel 4. Hasil uji eksperimental dan analisis MEH benda uji IPE $\mathbf{3 3 0}$

\begin{tabular}{lrrr}
\hline \multicolumn{1}{c}{ Analisis } & $\begin{array}{c}\mathbf{P}_{\max } \\
(\mathbf{k N})\end{array}$ & $\begin{array}{c}\Delta \mathbf{v} \\
(\mathbf{m m})\end{array}$ & $\begin{array}{c}\Delta \mathbf{H} \\
(\mathbf{m m})\end{array}$ \\
\hline Eksperimental & 176,600 & 24,500 & 62,300 \\
MEH & 171,800 & 26,430 & 76,467 \\
Rasio & 1,027 & 0,926 & 0,814 \\
\hline
\end{tabular}




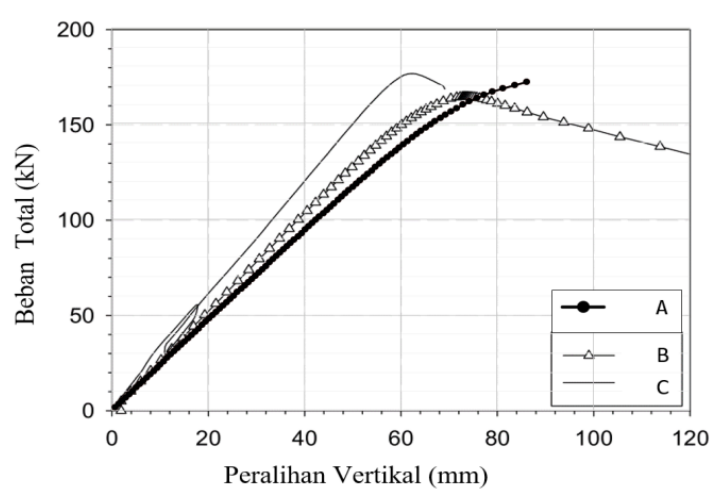

Gambar 6. Hubungan beban total dan peralihan vertikal benda Uji IPE $\mathbf{3 3 0}$

\section{Uji konvergensi}

Pada analisis metode elemen hingga, jumlah elemen diskret yang digunakan mempengaruhi tingkat ketelitian analisis. Ukuran elemen diskret yang semakin kecil akan menghasilkan jumlah elemen diskret yang semakin banyak pada benda uji yang sama. Untuk mengetahui pengaruh jumlah elemen diskret terhadap tingkat ketelitian analisis, perlu dilakukan uji konvergensi. Pada studi ini, uji konvergensi dilakukan pada balok cellular $\mathrm{CF}$ $225 \times 75 \times 5 \times 7$ yang mengalami tekuk torsi lateral dengan panjang bentang tak tertumpu lateral 2441,25 mm. Pembebanan dan tumpuan yang digunakan sama dengan pemodelan yang telah dijelaskan pada subbab sebelumnya. Elemen diskret yang digunakan adalah SHELL281. Jumlah elemen diskret divariasikan sehingga dapat menghasilkan momen kritis maksimum yang berbeda-beda. Hasil dari uji ini adalah hubungan antara momen kritis terhadap jumlah elemen diskret yang digunakan, yang ditampilkan pada Tabel 5 dan grafik pada Gambar 7.

Tabel 5. Momen kritis tekuk torsi lateral balok cellular CF 225x75×5x7 terhadap berbagai ukuran elemen diskret

\begin{tabular}{ccc}
\hline $\begin{array}{c}\text { Ukuran Elemen } \\
\text { Diskret } \\
\text { Terbesar (mm) }\end{array}$ & $\begin{array}{c}\text { Jumlah } \\
\text { elemen } \\
\text { diskret }\end{array}$ & $\begin{array}{c}\boldsymbol{M}_{\boldsymbol{c r} \text {-MEH }} \\
\mathbf{( k N m )}\end{array}$ \\
\hline 90,00 & 280 & 24,229 \\
75,00 & 280 & 22,398 \\
50,00 & 447 & 21,971 \\
40,00 & 512 & 21,910 \\
30,00 & 1.137 & 21,758 \\
25,00 & 1.431 & 21,758 \\
20,00 & 1.880 & 21,727 \\
15,00 & 3.534 & 21,727 \\
10,00 & 7.315 & 21,666 \\
\hline
\end{tabular}

Berdasarkan uji konvergensi ukuran elemen diskret pada balok cellular $\mathrm{CF} 225 \times 75 \times 5 \times 7$, diperoleh hubungan momen kritis dan jumlah elemen diskret yang ditampilkan pada Gambar 7. Berdasarkan Gambar 7, momen kritis menjadi konvergen ketika elemen diskret yang digunakan berjumlah dari sekitar 1.000 elemen dan telah konvergen dengan jumlah elemen 7.315. Pada analisis menggunakan metode elemen hingga, semakin banyak jumlah elemen yang digunakan maka momen kritis yang dihasilkan akan semakin mendekati angka tertentu atau menjadi konvergen.

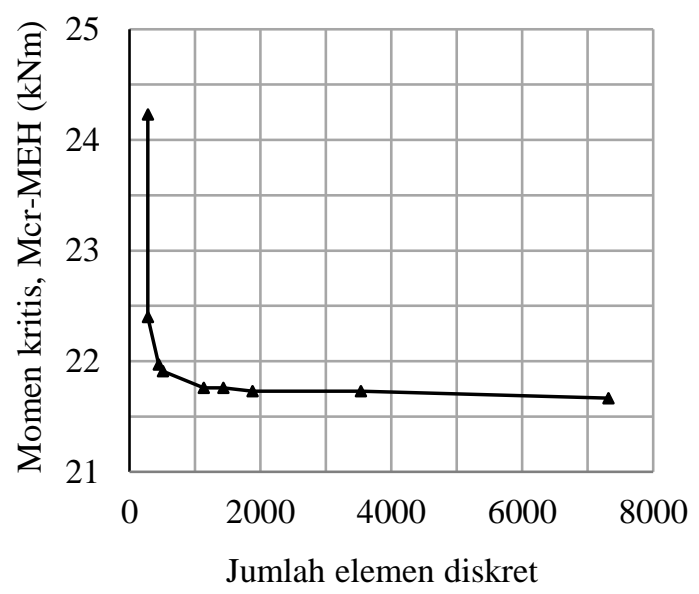

Gambar 7 Hubungan momen kritis dan jumlah elemen diskret

Tabel 6. Momen kritis balok cellular CF225x75x5x7 terhadap jumlah substep

\begin{tabular}{cc}
\hline Jumlah substep & $\begin{array}{c}\boldsymbol{M}_{\boldsymbol{c r}-\mathbf{M E H}} \\
(\mathbf{k N m})\end{array}$ \\
\hline 20 & 21.666 \\
40 & 21.696 \\
60 & 21.696 \\
80 & 21.666 \\
100 & 21.696 \\
200 & 21.666 \\
\hline
\end{tabular}

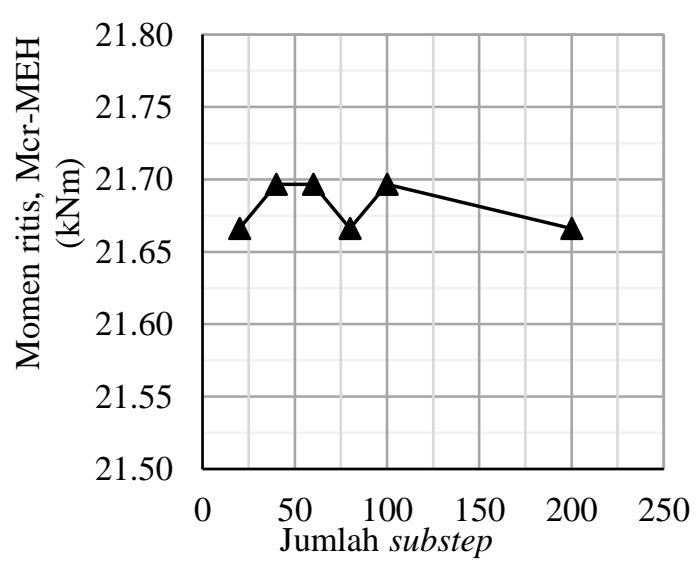

Gambar 8 Hubungan Mcr-MEH dan jumlah substep pada balok CF $225 \times 75 \times 5 \times 7$ dengan ukuran elemen diskret $10 \mathrm{~mm}$ 
Selain uji konvergensi ukuran elemen diskret, juga dilakukan uji kehalusan tahapan inkrementasi beban. Pada perangkat lunak ANSYS, tahapan inkrementasi beban diatur menggunakan perintah substep. Jumlah substep menentukan inkrementasi beban yang dikerjakan pada analisis tekuk nonlinier.

\section{Analisis tekuk nonlinier}

\section{Peralihan lateral}

Dengan cara load control, analisis akan dihentikan ketika beban mencapai nilai yang menyebabkan struktur mengalami keruntuhan. Dengan cara tersebut, perilaku postbuckling tidak dapat diperoleh sehingga peralihan lateral maksimum diperoleh berdasarkan beban maksimum ketika struktur runtuh. Hubungan antara peralihan dan resultan beban ditampilkan pada Gambar 9 sampai dengan 12. Resultan beban merupakan perkalian antara beban terbagi rata dengan luas permukaan yang terbebani. Peralihan lateral maksimum yang terjadi pada balok dengan bentang yang lebih pendek memiliki nilai yang lebih kecil dibandingkan dengan balok dengan bentang yang lebih panjang. Semakin panjang bentang balok maka beban maksimum yang dapat dipikul semakin rendah tetapi peralihan maksimum yang terjadi semakin tinggi. Hal ini mengindikasikan bahwa panjang balok mempengaruhi beban maksimum dan peralihan lateral maksimum yang terjadi balok yang mengalami tekuk torsi lateral.

Peralihan yang terjadi pada awal pembebanan masih bersifat elastis, hal ini dapat dilihat pada garis hubungan momen lentur dan peralihan lateral yang masih bersifat linier. Seiring dengan meningkatnya momen lentur, balok cellular mengalami peningkatan peralihan lateral yang semakin besar sehingga hubungan antara momen lentur dengan peralihan tidak lagi linier. Balok cellular dengan bentang panjang mengalami peralihan lateral maksimum yang lebih besar dibandingkan dengan bentang yang lebih pendek.

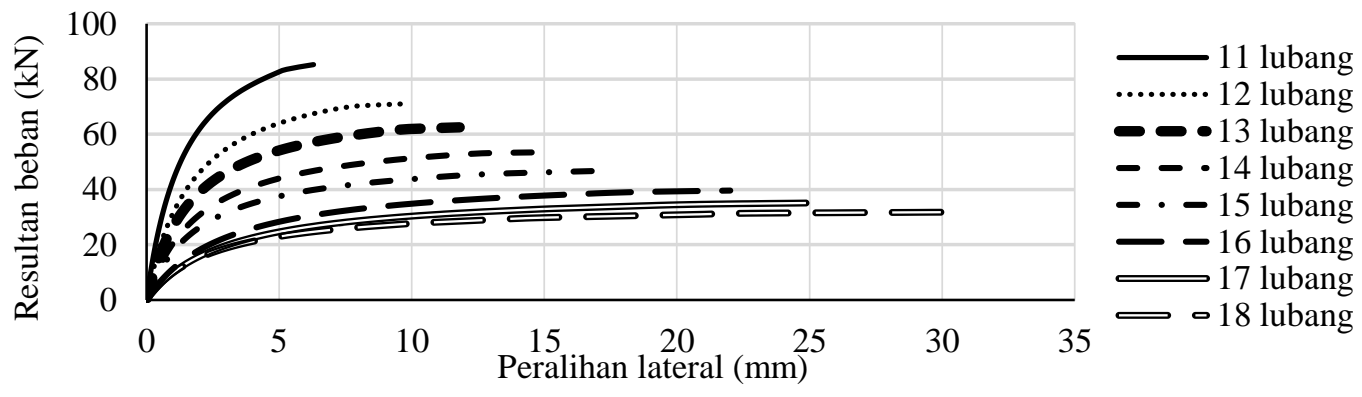

Gambar 9. Hubungan resultan beban dan peralihan lateral untuk profil CF225x75x5x7

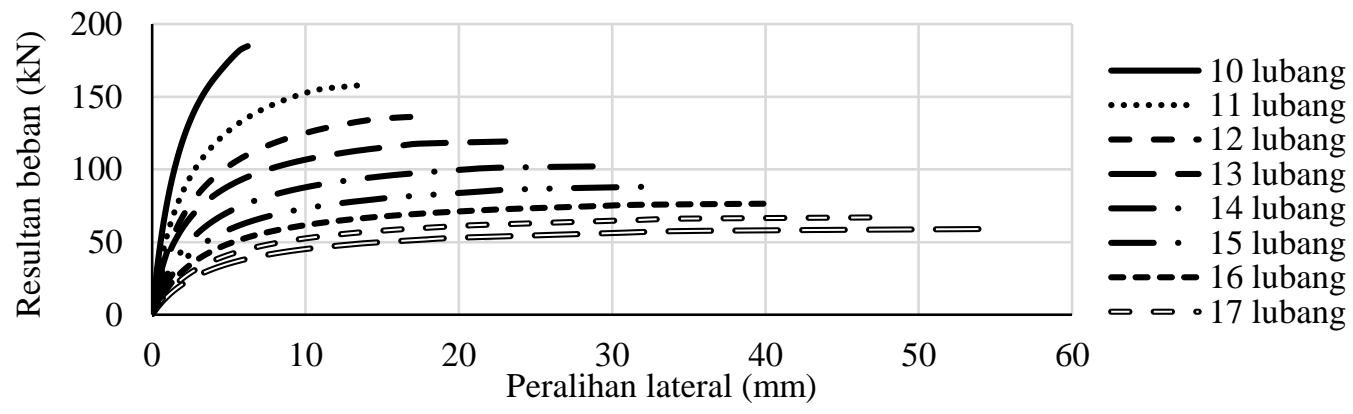

Gambar 10. Hubungan resultan beban dan peralihan lateral untuk profil CF 375x125x6x9

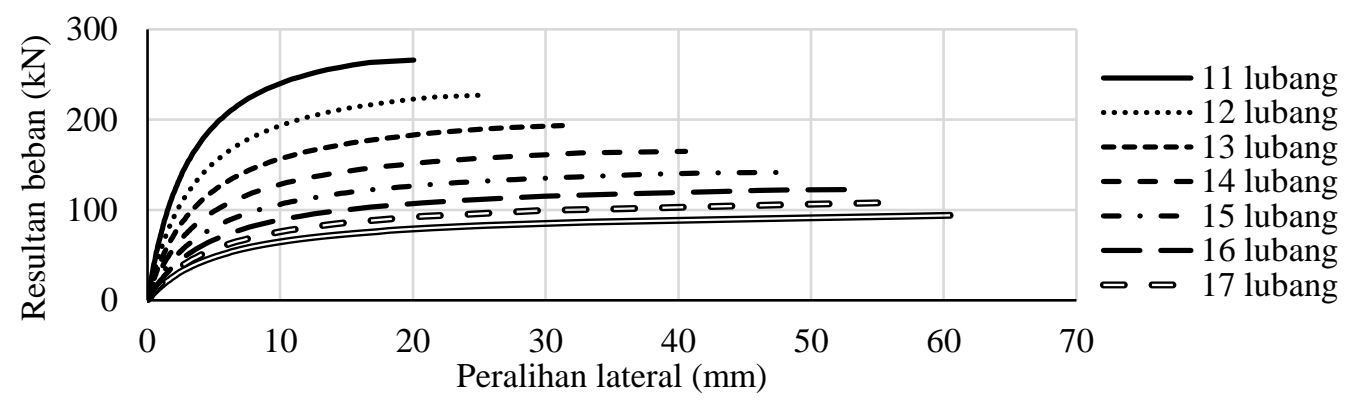

Gambar 11. Hubungan resultan beban dan peralihan lateral untuk profil CF 525x175x7x11 


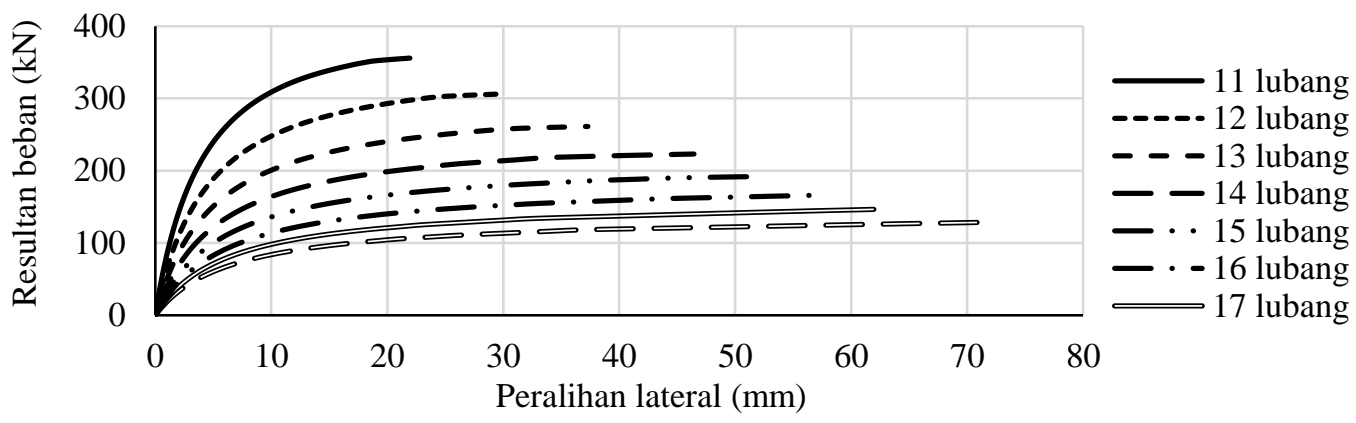

Gambar 12. Hubungan resultan beban dan peralihan lateral untuk profil CF $600 \times 200 \times 8 \times 13$

Tabel 7. Momen kritis tekuk torsi lateral nonlinier metode elemen hingga dan persamaan AISC

\begin{tabular}{|c|c|c|c|c|c|}
\hline Profil & $\boldsymbol{L}_{b} / \boldsymbol{r}_{t s}$ & $\begin{array}{c}M_{c r-A I S C} \\
(\mathbf{k N m})\end{array}$ & $\begin{array}{c}M_{c r-M E H} \\
(\mathbf{k N m})\end{array}$ & Persentase $(\%)$ & $M_{c r-M E H} / M_{c r-A I S C}$ \\
\hline \multirow{8}{*}{ CF $225 \times 175 \times 5 \times 7$} & 116,87 & 31,216 & 22,812 & $-31,65$ & 0,731 \\
\hline & 126,95 & 28,983 & 21,666 & $-31,37$ & 0,748 \\
\hline & 137,02 & 25,877 & 20,586 & $-25,70$ & 0,796 \\
\hline & 147,10 & 23,372 & 19,023 & $-23,55$ & 0,814 \\
\hline & 157,17 & 21,299 & 17,682 & $-20,46$ & 0,830 \\
\hline & 167,25 & 19,559 & 16,523 & $-22,85$ & 0,845 \\
\hline & 177,32 & 18,081 & 15,516 & $-20,85$ & 0,858 \\
\hline & 187,40 & 16,810 & 14,640 & $-17,35$ & 0,871 \\
\hline \multirow{9}{*}{ CF $325 \times 125 \times 6 \times 9$} & 106,68 & 113,385 & 78,967 & $-43,58$ & 0,696 \\
\hline & 116,75 & 104,625 & 74,072 & $-41,25$ & 0,708 \\
\hline & 126,81 & 91,471 & 69,384 & $-31,83$ & 0,759 \\
\hline & 136,87 & 80,833 & 65,351 & $-23,69$ & 0,808 \\
\hline & 146,94 & 72,242 & 60,328 & $-19,75$ & 0,835 \\
\hline & 157,00 & 65,192 & 55,341 & $-17,80$ & 0,849 \\
\hline & 167,07 & 59,325 & 51,126 & $-16,04$ & 0,862 \\
\hline & 177,13 & 54,380 & 47,537 & $-14,40$ & 0,874 \\
\hline & 187,01 & 50,166 & 44,239 & $-13,40$ & 0,882 \\
\hline \multirow{8}{*}{ CF $525 \times 175 \times 7 \times 11$} & 116,46 & 240,713 & 174,047 & $-38,30$ & 0,723 \\
\hline & 126,49 & 208,742 & 161,617 & $-29,16$ & 0,774 \\
\hline & 136,53 & 183,460 & 148,439 & $-23,59$ & 0,809 \\
\hline & 146,57 & 163,098 & 135,800 & $-20,10$ & 0,833 \\
\hline & 156,61 & 146,436 & 124,599 & $-17,53$ & 0,851 \\
\hline & 166,65 & 132,610 & 114,889 & $-15,42$ & 0,866 \\
\hline & 176,69 & 120,996 & 106,423 & $-13,69$ & 0,880 \\
\hline & 186,73 & 111,133 & 98,726 & $-12,57$ & 0,888 \\
\hline \multirow{8}{*}{ CF 600x200x8x13 } & 115,78 & 374,227 & 265,768 & $-40,81$ & 0,710 \\
\hline & 125,76 & 324,734 & 248,285 & $-30,79$ & 0,765 \\
\hline & 135,75 & 285,586 & 228,768 & $-24,84$ & 0,801 \\
\hline & 145,73 & 254,048 & 209,780 & $-21,10$ & 0,826 \\
\hline & 155,71 & 228,233 & 193,017 & $-18,25$ & 0,846 \\
\hline & 165,69 & 206,806 & 177,926 & $-16,23$ & 0,860 \\
\hline & 175,67 & 188,800 & 166,098 & $-13,67$ & 0,880 \\
\hline & 185,65 & 173,502 & 154,222 & $-12,50$ & 0,889 \\
\hline
\end{tabular}

2. Momen kritis tekuk torsi lateral

Berdasarkan analisis tekuk nonlinier menggunakan metode elemen hingga, diperoleh momen kritis yang menyebabkan balok cellular mengalami keruntuhan dengan ragam tekuk torsi lateral. Tekuk torsi lateral pada balok cellular terjadi setelah sebagian besar struktur mengalami tegangan leleh, sehingga dapat dsiimpulkan bahwa tekuk yang terjadi adalah tekuk torsi lateral inelastis.

Momen kritis analisis tekuk nonlinier kemudian akan dibandingkan dengan momen kritis spesifikasi AISC 360-16 yang menggunakan data penampang prismatis. Hasil momen kritis analisis ini ditabelkan pada Tabel 7. Pada Tabel 7, persentase perbedaan antara momen kritis 
spesifikasi AISC 360-16 dengan momen kritis analisis metode elemen hingga terletak pada rentang antara $12,5 \%$ hingga $43,58 \%$. Tanda negatif pada kolom persentase perbedaan menunjukkan $M_{c r-M E H}$ lebih kecil dari pada $M_{c r-A I S C}$. Data pada Tabel 7 dapat diplot sehingga didapatkan plot data hubungan antara rasio momen terhadap $L_{b} / r_{t s}$ yang ditampilkan pada Gambar 13 .

Besarnya variabel $C_{\text {corr }}$ dapat diperoleh berdasarkan data yang diperoleh pada Tabel 7 yaitu rasio momen kritis tekuk torsi lateral. Maka faktor koreksi dapat dihubungkan dengan besaran penampang berupa $C_{s r}$ dan $C_{s e c}$ dengan menggunakan metode statistik. $C_{s r}$ merupakan variabel kelangsingan balok yang dihitung dengan Persamaan 7 dan $C_{\text {sec }}$ merupakan variabel penampang yang dihitung dengan persamaan 8 . Kedua variabel ini merupakan variabel tak bersatuan.

$C_{s r}=\frac{r_{t s}}{L_{b}}$

$C_{\text {sec }}=\frac{s_{x} h_{0}}{J}$

Pada studi ini, digunakan perangkat lunak Minitab untuk memperoleh persamaan regresi berdasarkan data pada Tabel 7. Berdasarkan analisis dengan metode statistik, diperoleh persamaan regresi berikut (Persamaan 10):

$C_{\text {corr }}=1,25193-62,21815 C_{s r}$

$-6,64323 C_{s e c}+893,70823\left(C_{s r} * C_{s e c}\right)$

Dalam memperoleh persamaan regresi, koefisien determinasi $\left(\mathrm{R}^{2}\right)$ menjadi acuan dasar yang menentukan tingkat pengaruh variabel bebas terhadap variabel terikat. Dalam analisis ini, yang merupakan variabel terikat adalah $C_{\text {corr }}$ dan variabel bebas adalah variabel $C_{s e c}$ dan $C_{s r}$. Koefisien determinasi $\left(\mathrm{R}^{2}\right)$ yang diperoleh persamaan 9 adalah 0,9724. Persamaan 9 dapat diplot menjadi suatu regresi permukaan yang ditampilkan pada Gambar 14.

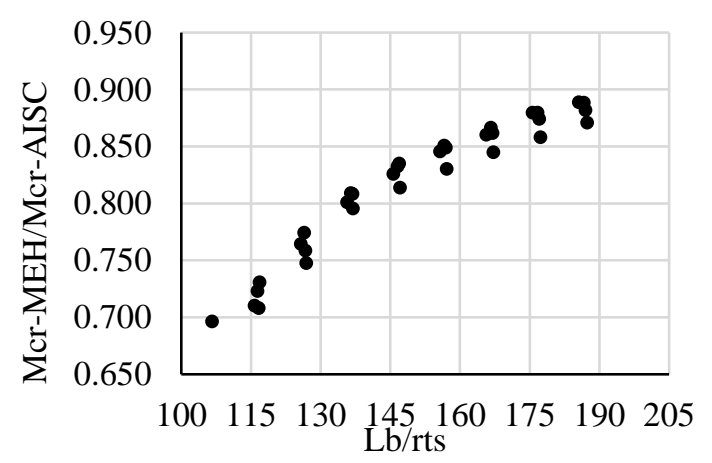

Gambar 13. Plot rasio momen kritis tekuk torsi lateral terhadap Lb/rts

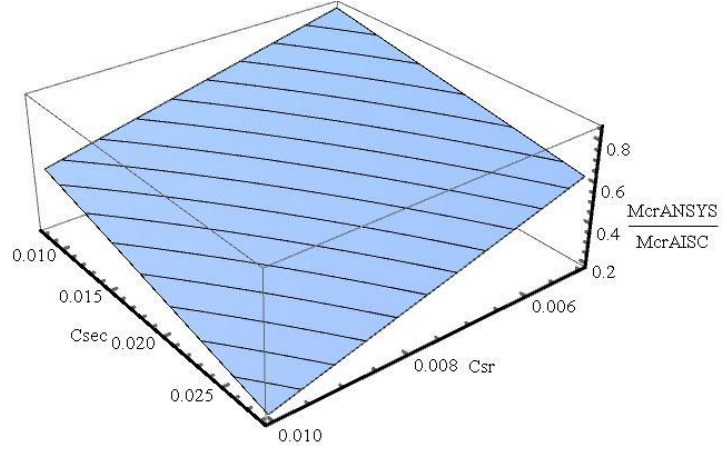

Gambar 14. Regresi permukaan persamaan faktor koreksi momen kritis tekuk torsi lateral balok celullar

Dengan memperoleh $\mathrm{C}_{\text {corr }}$, maka momen kritis tekuk torsi lateral untuk balok cellular dapat dihitung dengan memanfaatkan persamaan pada spesifikasi AISC. Persamaan ini ditampilkan pada Persamaan 10.

$M_{c r-M E H}=C_{c o r r} * M_{c r-A I S C}$

\section{Persamaan momen kritis tekuk torsi lateral}

Untuk memperoleh faktor koreksi persamaan AISC untuk balok cellular, akan digunakan perbandingan antara momen kritis balok cellular dengan momen kritis balok I prismatis yang dihitung menggunakan persamaan AISC 360-16. Persamaan yang akan digunakan untuk menghubungkan kedua besaran tersebut ditampilkan dalam Persamaan 11 menggunakan variabel $C_{\text {corr }}$ sebagai faktor koreksi.

$C_{\text {corr }}=\frac{M_{c r-M E H}}{M_{c r-A I S C}}$

\section{Kesimpulan}

Berdasarkan analisis yang telah dilakukan, diperoleh beberapa kesimpulan bahwa momen kritis balok cellular yang diperoleh menggunakan metode elemen hingga lebih kecil daripada momen kritis spesifikasi AISC 360-16 dengan persentase perbedaan pada rentang antara 12,5\% hingga 43,58\%. Untuk balok cellular, semakin rendah $\mathrm{L}_{\mathrm{b} / \mathrm{r}_{\mathrm{ts}}}$ maka perbedaan antara momen kritis persamaan AISC $\left(\mathrm{M}_{\mathrm{cr}-A I S C}\right)$ terhadap momen kritis tekuk nonlinier analisis metode elemen hingga ( $\left.\mathrm{M}_{\mathrm{cr}-\mathrm{MEH}}\right)$ semakin besar.

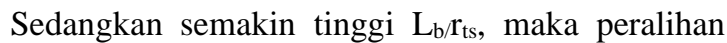
lateral maksimum yang terjadi juga semakin besar. Sebuah persamaan telah diperoleh, yaitu persamaan 11, untuk mengestimasi momen kritis tekuk torsi lateral balok cellular dengan memanfaatkan spesifikasi desain AISC 360-16. 


\section{Ucapan Terima Kasih}

Ucapan terima kasih ditujukan kepada Universitas Katolik Parahyangan yang telah memberikan izin agar penulis dapat menggunakan perangkat lunak ANSYS yang telah dimiliki lisensinya.

\section{Daftar Pustaka}

American Institute of Steel Construction. (2010). Specification for structural steel buildings. Chicago: Ill.

American Institute of Steel Construction. (2016). Specification for structural steel buildings. Chicago, Ill.

American Institute of Steel Construction. (2016). Steel design guide 31 - castellated and cellular beam design. Lawrence, Kansas.

Bak, Michael. (2014). "Nonlinier Buckling Analysis Using Workbench v15". CAE Associates, Engineering Consulting Firm in Middlebury, CT specializing in FEA and CFD analysis.

Cook, R., Malkus, D. S., Plesha, M. E. \& Witt, R. J. (2002). Concepts and applications of finite element analysis (4 ${ }^{\text {th }}$ ed.). New York: John Wiley and Sons.

Galambos, T. V., \& Surovek, A. E. (2008). Structural stability of steel. New Jersey: John Wiley \& Sons.

Gunawan D. \& Suryoatmono B. (2017). Numerical Study on Lateral-Torsional Buckling of Honeycomb Beam. Procedia Engineering, 171,140 -146 .

Höglund, T. (2006). Att konstruera med stål, Modul 6 - Stabilitet för balkar och stänger. Stockholm: Stålbyggnadsinstitutet.

Jamadar, A. M. \& Kumbhar, P. D. (2015). Parametric Study of Castellated Beam with Circular and Diamond Shaped Openings.
International Research Journal of Engineering and Technology, 2(2), 715-722.

Krzysztof, K. (2016). Failure Modes Determining the Resistance and The Stability of Steel Cellular Beams. Journal of Civil Engineering, Environment and Architecture, 62 (4/15), 263-280.

Kwani, S. \& Wjaya, P. (2017). Lateral Torsional Buckling of Castellated Beams Analyzed Using the Collapse Analysis. Procedia Engineering, 171, 813-820.

Lee, H. (2014). Finite Element Simulations with ANSYS Workbench 15. USA: Stephen Schroff.

Nseir, J., Somja, H., (2012, April). Lateral Torsional Buckling of Cellular Steel Beams. Proceedings of the Annual Stability Conference, Structural Stability Research Council, Grapevine, Texas.

Salmon, Charles G., Johnson, John E., Malhas, Faris A. (2009). Steel structures design and behaviour $\left(5^{\text {th }}\right.$ ed.). USA: Pearson International Edition.

Sehwail, M.M. (2013). Lateral Torsional Buckling of Steel I-Section Cellular Beams. Master thesis. Eastern Mediterranean University, Gazimağusa, North Cyprus.

Showkati H. (2008). Lateral-Torsional Buckling of Castellated Beams. Iranian Journal of Science \& Technologyi Transaction B, Engineering, 32(B2), 153-156.

Tudjono, S., Sunarto, \& Han, A. L. (2017). Analysis of Castellated Steel Beam with Oval Openings. IOP Conference Series: Materials Science and Engineering, 271, 012104.

Wakchaure, M. R. \& Sagade, A.V. (2012). Finite Element Analysis of Castellated Steel Beam. International Journal of Engineering and Innovative Technology, 2(1), 365-370. 